\title{
Career and Technical Education Industry Credentials and Its Potential Impact on a State's Economy
}

\author{
Anjanette Hendricks \\ Virginia Beach Public Schools
}

\author{
Steve Myran \\ Old Dominion University
}

Petros J. Katsioloudis

Old Dominion University

\author{
William Owings \\ Old Dominion University
}

\author{
Leslie Kaplan \\ Newport News Public Schools (Retired)
}

\begin{abstract}
As America's key industries offer high salaries in return for candidates with the necessary abilities and credentials to fill their vacancies, the knowledge, skills, and third-party industry credentials earned in secondary Career and Technical Education (CTE) programs seem a close match. Using a nonexperimental, quantitative study, this research shows in prospective dollars earned and tax revenues collected for five years of CTE industry credentials' the economic value for students and Virginia's treasury. The implications of this research enable policymakers, school leaders, and CTE advocates to reshape popular misperceptions of CTE and industry credentials, enhance high school students' career and postsecondary education outcomes, and add to state treasuries.
\end{abstract}

Keywords: career and technical education (CTE), industry recognized credentials, "middle jobs" jobs, soft skills, college and career readiness, state and local economies

\section{RETHINKING WHO IS SKILLED}

The demand for a skilled workforce is growing faster than the supply of workers with BA degrees. Since 1980, employment requiring higher levels of analytic skills has increased by $77 \%$, and jobs requiring stronger social skills have grown by $83 \%$ (Pew Research Center, 2018). Although popular belief deems earning a 4-year college degree as the golden path for upward mobility, higher incomes, and increased job stability, this assumption is "deeply flawed" (Lohr, 2020). By themselves, college degrees cannot be presumed as a proxy for employable skills. In fact, new research suggests that as many as 30 million U.S. 
workers without a 4-year college degree have the skills to move into new jobs that pay, on average, $70 \%$ more than their current ones (Blair, et al., 2020). As Peter Q. Blair, a Harvard labor economist, and his colleagues suggest, we need to rethink who is skilled, and how skills are measured and evaluated (Blair, et al., 2020). Talent can appear through may alternate routes (Opportunity@Work \& Accenture [O@W], 2020).

Research is clear: "A strong vocational program that prepares students to enter the workplace or to move on to further education and training benefits not only the individual students, but the entire economy those students will eventually support" (Kraemer \& Craw, 2020).

Offered in both middle and high schools, CTE programs aim to provide all students with the academic and technical skills necessary to succeed in future careers and postsecondary education (Association for Career \& Technical Education [ACTE], 2019a). However, the literature surrounding CTE and industry credentials is limited (Brand, 2008; Education Strategy Group et al. [ESG], 2018; Muller \& Beatty, 2009). Although federal and state governments have recently acknowledged CTE's value in meeting labor market needs and state/national economic growth (Alliance for Excellence in Education, 2019), much remains to be done if public schools are to equip every student for success in today's high-skills marketplace and postsecondary education.

This study adds to the literature about CTE's role in their region and state's labor market and for individuals' prospects for well-paying work and lifelong learning. Current research data are needed if state and local policymakers are to make informed decisions that advance the needs of their students and community, regional, and state economies.

\section{THE CTE POLICY CLIMATE}

High quality CTE helps fortify ties and transitions between secondary and postsecondary education and the labor market. Once known derisively as "voc-ed", CTE programs have morphed into a rigorous academic and occupational response to globalization, technological advances, and an aging workforce to meet our evolving economic and career environments. Today, CTE enrolls students from across the academic spectrum to develop academic and technical competencies that are foundational to more advanced skill development across a wide array of industry sectors and occupations. Moreover, these documentable skills are portable; employers in a wide range of occupations nationwide recognize them. Research shows that these skills support higher student academic achievement, increase high school and college graduation rates, and promote job satisfaction (Elchert, et al., 2017). In addition, data from the National Center for Education Statistics (NCES) show that during the 2010-2011 academic year, 34\% of high school CTE students $(600,000)$ took dual college credit course college credits through a CTE course (Thomas, et al., 2013).

Academically, CTE's approach centers instruction in a career with a real-world context, bringing abstract concepts - such as the practical applications of mathematics and reading comprehension - to practical relevance. Its coursework spans the continuum from career exploration to advanced technical training, helping students develop fundamental skills including the ability to think critically, solve problems, and work collaboratively - essential workplace and higher education skills (ACT, 2018). Moreover, CTE's flexibility enables students to select their own educational and career pathways and shift direction as their interests and competencies evolve (ACT, 2018). In short, CTE has become less of a "track" for low-income and low-achieving students and more of a "field" - such as STEM - in which youths from a wide array of backgrounds and interests share (U.S. Department of Education [USDOE], 2013).

But while overall CTE participation remains steady, the proportion of students concentrating in CTE (that is, enrolled in three or more courses in the same occupational sequence) has declined since the 1980s. Beginning in 2006 with Perkins IV, the 1984 Carl D. Perkins law's fourth reauthorization, the federal legislation funding CTE programs emphasizes raising the academic and technical rigor of secondary and postsecondary CTE instruction to prepare students for entry into high-skill, high-wage, or high-demand occupations (USDOE, 2013). 
Yet as compared with its international peers, U.S. CTE programs are not faring well (Field, et al., 2010). After studying demographic changes, labor market needs, and student involvement in vocational educational training (VET) in 17 countries, the Organisation for Economic Cooperation and Development (OECD) concluded that the United States had "virtually no students" in vocational education and training (Tucker, 2018). Moreover, whereas 20 percent of American students take a three-course sequence in career and technical education, and 75 percent take at least one course (Tucker, 2018), Switzerland's "typical" VET students spend three full eight-hour days, 40 weeks a year for three years in a highly-structured apprenticeship at a worksite, with at least one more day each week in a school learning the theory behind the work" (Tucker, 2018).

According to Passarella (2018), OECD leading nations' more robust connections among education, industry, and government explains this difference in program quality. Likewise, the undergirding contrast between the U.S. and OECD appears in VET's purpose. OECD's VET programs intend for students to acquire meaningful attitudes, high level knowledge and skills, and credentials that command such real value to future employers that they are willing to pay these credentialled students a substantially higher salary than to students without the credentials (Tucker, 2018). In the U.S., roughly 6\% of students concentrate in CTE pathways as compared with $42 \%$ in the United Kingdom, $59 \%$ in Germany, and $64 \%$ in Switzerland (USDOE, 2013).

To address this, in 2018, Congress passed the Strengthening Career and Technical Education for the $21^{\text {st }}$ Century Act (Perkins V) (Congress.gov, 2018). Perkins V requires states and school divisions to meet new program quality standards by including at least one of the following indicators in their Perkins $\mathrm{V}$ accountability system: (a) the percentage of CTE concentrators who graduated from high school having attained a recognized postsecondary credential; (b) the percentage of CTE concentrators who graduated from high school having attained postsecondary credits in the relevant CTE program of study earned through dual enrollment or concurrent enrollment or another credit transfer; or (c) the percentage of CTE concentrators who graduated from high school having participated in work-based learning (Alliance for Education, 2019, p. 4). While this law does not take effect until 2021, secondary schools need more information about CTE's and industry credentials' personal and economic value if they are to meet this higher-quality criteria.

\section{CTE'S CONTRADICTIONS}

The literature on CTE, industry credentials and the economic marketplace stresses a common theme: the contradiction between CTE's purpose and value in helping students prepare for academic and occupational success in a fast changing, high-tech economy versus the declining number of students enrolled in CTE industry credential programs (Malkus, 2019).

Despite CTE's intentions, in reality, too few students avail themselves of this opportunity. In part, this decline may reflect students' increased academic course taking (ACT, 2018). Further, over the past six years, Virginia Department of Education (VDOE) data show increasing numbers of high school students completing the "soft skills" credentials such as "Workplace Readiness Skills" and "Financial Literacy" as part of its school accountability program. But as Table 1 indicates, these one-credit courses continue to see the largest enrollments of any single credential earned as compared with peers completing a technical certification (VDOE, 2019). While these one-credit certifications indicate to employers that the individual has the qualities and habits important to workplace success, such as punctuality, self-discipline, effective communications and organizational skills (Muller \& Beatty, 2009), their worth as a Virginia Boardapproved industry credential is questionable. 


\section{TABLE 1}

NUMBER OF ASSESSMENTS PASSED: 2011-2017

\begin{tabular}{cccc}
\hline Year & $\begin{array}{c}\text { Workplace Readiness Skills for } \\
\text { Commonwealth Assessment }\end{array}$ & $\begin{array}{c}\text { Financial } \\
\text { Literacy }\end{array}$ & $\begin{array}{c}\text { Largest single number per } \\
\text { technical certification }\end{array}$ \\
\hline $2016-2017$ & 42,313 & 64,915 & 5,123 (CSP) \\
$2015-2016$ & 30,775 & 59,569 & 5,105 (MOS: Word) \\
$2014-2015$ & 33,665 & 55,817 & 3,552 (CSP) \\
$2013-2014$ & 28,349 & 39,313 & 4,648 (CS) \\
$2012-2013$ & 21,312 & 11,821 & 5,132 (CSP) \\
$2011-2012$ & 13,605 & 4,074 & 5,401 (CSP) \\
\hline
\end{tabular}

Note: Data retrieved from VDOE (2019). The path to industry certification: High school industry credentialing. http://www.doe.virginia.gov/instruction/career_technical/path_industry_certification/index.shtml

This trend also may reflect CTE's traditional stigma and marginalized status among the general population (ACTE, 2019b; Kandalec, 2016). Many mistakenly perceive that CTE lacks academic rigor; leads to antiquated, undesirable, or low-paying jobs; limits access to college; and serves only low performing students (Brand, 2008). Schools' practice of "tracking" low-income and minority students into low-income occupational courses does little to burnish CTE's image (Malkus, 2019). The negative perception surrounding CTE also raises the "persistent question of prestige and class" (Kandalec, 2016, p. 25 ) that may also limit its attractiveness to students. Likewise, CTE's poor showing vis-à-vis international VET comparisons further reinforces this misperception (Field, et al., 2010).

Similarly, accountability pressures may sway high schools in ways that inadvertantly contribute to this outcome. Rather than place students into extended CTE programs that develop much-valued skills, some schools are "incentivized to encourage low-level credential attainment" to "game" the K-12 accountability system (ESG et al., 2018, p. 11) by enrolling students in CTE courses that provide no labor market value but simply to increase the school's on-time graduation rate and avoid "corrective actions" (VDOE, 2020b). Accountability pressures may also persuade many schools to include remedial and tutoring activities in students' schedules to raise test scores, crowding out time for extensive CTE involvement (Jacob, 2017).

Similarly, "credential confusion" may be a factor keeping CTE completer rates low (Zanville \& Essien, Jr., 2019). With more than 5,000 active certifications available in the United States (Prebil \& McCarthy, 2018), offerings vary state to state, are inconsistently defined, have differing requirements, and many certifying groups. Essentially, credentials sometimes cause students, educators, and employers uncertainty about their worth (ESG et al., 2018; Markow et al., 2017). As a result, the popular view of a 4-year college degree as the only "path to success" appears to predominate over the need for a skilled workforce in which students can secure one of the "Good Jobs That Pay Without a BA" (Carnevale et al., 2017).

Ironically, these "soft skills" certifications might undermine state efforts to promote "credentials of value." For instance, earned technical credentials demonstrate competence in skill areas such as A+ hardware and software technician assessment; Automotive Service Excellence (ASE) certifications; or Licensed Practical Nursing (LPN). By meeting the Perkins-required "quality indicator" through increased numbers of "soft skill" certifications rather than having students complete three or more credits within a single CTE pathway and earning industry-recognized credentials that the labor market needs and rewards, educators may be "checking an accountability box" but shortchanging students.

\section{THE STUDY}

To determine the economic value of industry-recognized credentials for high school students and to ascertain the state's treasury potential income tax revenue, the first author conducted a non-experimental, quantitative study using Virginia data. Specifically, the study intended to identify the trends for high school CTE participation and program completion with an industry-credential, the possible income for students 
earning industry credentials in Virginia's labor market, and the prospective economic impact for the state and region if the number of CTE students earning industry credentials were to increase by $10 \%$ annually.

\section{Ex Post Facto Data}

Data retrieved from the Industry Credential Assessment Data: 2012-2019 obtained from the VDOE Office of Education Information Management (S.M. Williams, personal communication, December 2, 2019) were used to identify the CTE industry credentials taken and passed in Virginia, by region, over five years. The researcher disaggregated these data into three categories: (a) "Technical" assessments (e.g., those indicating completion of a CTE program of study); (b) "Other" assessments (e.g., assessments taken at the primary level, rather than advanced, indicating that students are still on their CTE career pathway); and (c) "Soft Skills/College and Career Ready" assessments (e.g., assessments taken by high school students which compliment a general or specific course of study approved by the VDOE as CTE industry credentials). The investigator aligned these with data gathered from the Bureau of Labor Statistics' Occupational Outlook Handbook (Bureau of Labor Statistics [BLS], 2018) and Virginia's regional labor market data (Career and Technical Education [CTAE] 2018). These CTE industry credential data were then aligned to occupational openings in each superintendent region. With the occupation, mean salary, the number of annual openings projected to 2026, and the number of annual exits from these occupations identified, a potential income level for the student and revenue for the state's treasury were projected.

\section{Likert Survey Data}

To validate the alignment between the CTE industry credential and its related occupation, 10 CTE experts in two states, Virginia and Texas, a sample of convenience, were surveyed to indicate their level of agreement with the alignment using a 5-point Likert survey, where "one" indicated a low agreement, and "five" a high agreement. The survey also asked respondents to suggest possible other aligned occupations. Respondents' feedback was used to ensure all the alignments presented were in full agreement and to reduce researcher bias. Further, these data were used to confirm the prospective salaries available to candidates with a particular credential entering a designated career, enabling calculation of the economic impact the earnings could have on student, region, and state.

\section{Closed-Ended Question Survey}

Because CTE industry credentials provide its holder with increased human capital, industry and labor market representatives' feedback was considered vital to determine CTE industry credentials' actual workplace value. Using the online platform Survey Monkey, a 5-question survey was sent to representatives from several of Virginia's leading industries to determine their employment and salary-making decisions explicitly based on the potential employee's earned CTE industry credentials. The final question, openended, asked respondents to state the percentage salary increase (as determined by the previous four answers) a candidate with industry credentials starting employment with their company might receive. The survey's purpose was to determine a minimum percentage amount that an industry credential holder could earn. While the responses ranged from $5 \%$ to $25 \%$ salary increase, the $10 \%$ figure was used in the final calculations since six of the 18 respondents indicated this preference.

Study limitations include using a sample of convenience for CTE administrators in Virginia and Texas rather than one randomly selected. Another limitation is the 18 out of 40 Virginia industry representatives' response rates, but these persons speak for large Virginia companies and industries. Although one cannot generalize on these findings beyond Virginia, the $10 \%$ value-added figure of a starting salary is conceivable. Further study in other states may increase the findings' generalizability.

\section{RESULTS AND DISCUSSION}

In the study's most notable finding, each Virginia CTE completer student with industry credentials has the potential to earn an average salary of $\$ 54,311$ in Virginia's labor market. If the number of CTE completers were to increase by an average of four students annually in each Virginia high school and 
technical center, the state's treasury could increase by $\$ 52,647,744.83$ annually or $\$ 263,238,724.16$ over five years (Table 2). However, with an average annual increase rate in the number of Virginia's CTE completers standing at $0.2 \%, 69 \%$ of CTE industry credentials taking the "Soft Skills/College and Career Readiness" and only 14\% of CTE students earning "Technical" industry validated credentials (author computed from data provided by S.M. Williams, personal communication, December 2, 2019), the contradiction between CTE's purpose and value and the enrollment realities are clear. This trend was present in each of the eight Superintendent regions.

TABLE 2

ESTIMATED FIGURES OF CTE COMPLETERS BY SCHOOL, AND INCOME TAX REVENUE WHEN INCREASED BY 10\% ANNUALLY OVER A FIVE-YEAR PERIOD

\begin{tabular}{cccccc}
\hline $\begin{array}{c}\text { Increased \# } \\
\text { Completers } \\
\text { per } \\
\text { School }\end{array}$ & $\begin{array}{c}\text { Starts at Regular Salary } \\
\text { Annual } \\
\text { Income Tax } \\
\text { Revenue Increase }\end{array}$ & $\begin{array}{c}\text { ToTAL } \\
\text { Income Tax } \\
\text { Revenue Increase } \\
\text { Over 5 Years }\end{array}$ & $\begin{array}{c}\text { Starts at 10\% Salary Increase } \\
\text { Annual } \\
\text { Income Tax } \\
\text { Revenue Increase }\end{array}$ & $\begin{array}{c}\text { TOTAL } \\
\text { Income Tax } \\
\text { Revenue Increase } \\
\text { Over 5 Years }\end{array}$ \\
\hline VA & 4 & $\$ 47,379,099.05$ & $\$ 236,895,495.25$ & $\$ 52,647,744.83$ & $\$ 263,238,724.16$ \\
\hline
\end{tabular}

Despite its potential benefits, trends over the past five years indicate that students are not earning the "Technical," CTE program-specific industry credentials in large numbers. When the VDOE Board validated industry credentials were disaggregated into the three categories of "Technical," "Other" and "Soft Skills/College \& Career Ready," the largest number of students were in the "Soft Skills/College \& Career Ready" category: $69 \%$ of students taking these assessments and $72 \%$ earning them. In contrast with the "Technical," CTE completer specific programs, 14\% of students took the assessment, and 11\% earned them.

More encouraging, the emergent trend, as seen in Figure 1, is the increased number of completers over time. The 7\% growth measure from 2016 to 2019 , and the rise of $9 \%$ from the lowest point of completers, indicates that the number of CTE completers is steadily increasing. Despite this growth, the largest growth measure of 7\% in a single year occurred in the academic years 2014-2015 to 2015-2016. If Virginia is to increase its number of completers by $10 \%$, it may take some time since the average level of growth generally, is $0.2 \%$.

FIGURE 1

VIRGINIA CTE COMPLETERS: 2014-2019

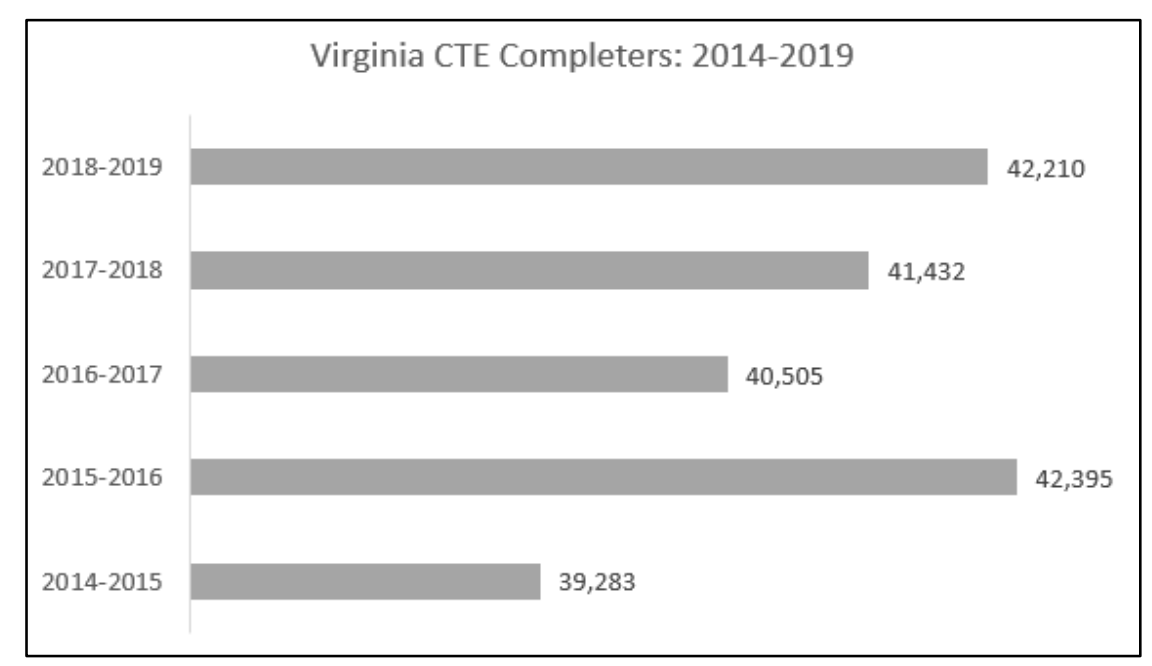


This study's findings align with prior research (Field, et al, 2010; Passarella, 2018; Tucker, 2018) that U.S. students are receiving minimal exposure to CTE courses. This appears especially true in Virginia. Although the OECD (Field, et al., 2010) report is dated, this limitation actually reinforces the point that the number of CTE students in completer programs remains low a decade later.

\section{QUESTIONS AND IMPLICATIONS FOR CTE}

Considering these outcomes prompts several questions for school leaders, CTE administrators, and CTE professional organizations. First, with an average growth rate of $0.2 \%$ as a Commonwealth, why is the number of CTE completers so low? Perhaps it is insufficient funding, since in FY 2014, Virginia spent 7\% less to educate each student than it did in FY2005 (Joint Legislative Audit and Review Commission [JLARC], 2015). Second, does not updating educators and wider communities about CTE's actual financial and academic benefits when students complete programs leading to industry certified credentials harm enrollments?

Third, because the CTE completer sequence requires two or more consecutive years in a CTE program, are school district Human Resources Departments actively recruiting and retaining the teaching faculty specializing in these areas? Or, as the national trend suggests, are CTE teachers retiring in large numbers without available replacements? (Leachman \& Mai, 2014). Possibly, a shortage of highly skilled CTE teachers results in the lack of CTE offerings at the completer level. Fourth, does this lack of sufficient highly skilled CTE instructors for completer programs result in allocating non-CTE teachers to instruct VDOE courses recognized as eligible to receive CTE industry credential, such as the Soft Skills/College and Career Readiness courses? Non-CTE endorsed teachers may lack the knowledge or enthusiasm to promote enrollment in advanced CTE courses. These questions merit further study.

Moreover, this research demonstrates the advantages of CTE's earned industry credentials for Virginia's students and the state's fiscal health. If over quarter of a billion dollars can be earned over five years, a calculation based on the small number of current CTE "Technical" completers, it is possible that a concerted effort could increase by $10 \%$ the number of completers each year, earning the state significantly higher revenues in future years. These funds could be allocated to incentivize, recruit, and retain industry professionals to become CTE educators as well widely communicate CTE's updated profile in ways that reduce its stigma.

It also important to note that when Virginia's General Assembly strengthened post-secondary education and workplace requirements (VDOE, 2020a), amending graduation requirements to include the successful completion of a technical education credential, it looked like it granted Virginia Association of Career and Technical Education Administrators [VACTEA]'s (2018) wish to retool and reskill the workforce. However, with the substantial gap in those completing CTE industry credential programs in favor of College and Career Ready assessments, it is logical to ask whether school decisions to increase the on-time graduation rate and avoid "corrective actions" could be at play. If $69 \%$ of students take College and Career Readiness assessments whereas only about $14 \%$ of students are earning technical credentials, one must ask how well high schools are affording young people the opportunity to gain the academic and technical skills essential to advance to postsecondary education and/or a career.

\section{CONCLUSION}

This study's findings show that if each Virginia high school and technical center added an average of four CTE students to its completer programs each year, the potential annual income tax revenue available to the states' treasury could increase by $\$ 47,379,099.05$ annually (or $\$ 52,647,744.83$ when accounting for the additional $10 \%$ ). Over five years, $\$ 236,895,495.25$ could be available to the state treasury. Since scant research exists regarding the relationship between earning CTE industry credentials in high school and its economic impact on students and state, this study's findings opens new ground for viewing CTE high school completion with industry credentials as a potential source of economic health. 


\section{ENDNOTE}

1. Calculations for potential average salary for a credential holder: Add together the mean annual wage (set by BLS) where experts agree the credentials will align (credential to occupational alignment) $=\$ 11,984,600$. Divide the sum of occupational mean annual wage $\$ 11,984,600$ by the total number of occupations listed and agreed to in the credential to occupational alignment $=242 . \$ 11,984,600 / 242=\$ 49,374$. Times $10 \%$ industry-credential salary bonus that prospective employers say they would add: $\$ 49,374+10 \%(\$ 4937)=$ $\$ 54,311$.

\section{REFERENCES}

ACT. (2018). Career \& technical education (2018 edition). ACT's Policy Platform. Retrieved from https://www.act.org/content/dam/act/unsecured/documents/pdfs/Policy-Platform-CTE-2018.pdf

Alliance for Excellence in Education. (2019). Innovating for equity and excellence: Recommendations to states for implementing the Strengthening Career and Technical Education for the 21st Century Act (Perkins V). Retrieved from https://all4ed.org/wp-content/uploads/2019/07/Perkins-StatePlan-Recs_FINAL.pdf

Association for Career and Technical Education (2019b). CTE stigma: A barrier to advancing access. Retrieved from https://www.acteonline.org/cte-stigma-a-barrier-to-advancing-access/

Association for Career and Technical Education. (2019a). ACTE strategic directiton and vision statement. Retrieved from https://www.acteonline.org/about/acte-mission-standards/

Blair, P.Q., Costagnino, T.G., Groshen, E.L., DeBroy, P., Auguste, B., Ahmed, S., . . B Bonavida, C. (2020, March). Searching for stars: Work experience as a job market signal for workers without bachelor's degrees. Working paper 26844. National Bureau of Economic Research. Retrieved from https://www.nber.org/system/files/working_papers/w26844/w26844.pdf

Brand, B. (2008). Supporting high quality career and technical education through federal and state policy. American Youth Policy Forum. Retrieved from http://www.usmayors.org/workforce/documents/10-10-08CTEMeetingPaper.pdf

Bureau of Labor Statistics. (2018). Occupational Outlook Handbook. Retrieved from $\mathrm{https}$ :/www.bls.gov/ooh/computer-and-information-technology/home.htm

Career Technical and Agricultural Education. (2018). Trailblazers: Career and technical education in Virginia. Retrieved from http://ctetrailblazers.org/labor-market-data/

Carnevale, A., Strohl, J.C., Cheah, B., \& Ridley, N. (2017). Good jobs that pay without a BA. Georgetown University: Center on Education and the Workforce. Retrieved from http://goodjobsdata.org/wp-content/uploads/Good-Jobs-wo-BA.pdf

Congress.gov. (2018). H.R. 2353 - Strengthening career and technical education for the 21st century act. Retrieved from https://www.congress.gov/bill/115th-congress/house-bill/2353

Education Strategy Group, Advance CTE., \& Council of Chief State school Officers (2018). Credential currency. How states can identify and promote credentials of value. Retrieved from https://ccsso.org/sites/default/files/2018-10/Credential_Currency_report.pdf

Elchert, D.M., Latino, C.A., Bobek, B.L., Way, J., \& Casillas, A. (2017). The importance of behavioral skills and navigation factors for education and work success. ACT. Retrieved from http://www.act.org/content/dam/act/unsecured/documents/R1633-behavior-and-navigation-201704.pdf

Field, S., Hoeckel, V.K., \& Kuczera, M. (2010). Synthesis report of the OECD reviews of vocational education and training: Learning for jobs. Organisation for Economic Co-operation and Development. Retrieved from http://www.oecd.org/education/skills-beyondschool/Learning\%20for\%20Jobs\%20book.pdf

Jacob, B. (2017). What we know about career and technical education in high school. Brookings. Retrieved from https://www.brookings.edu/research/what-we-know-about-career-and-technicaleducation-in-high-school/ 
Joint Legislative Audit and Review Commission. (2015). Efficiency and effectiveness of K-12 spending. Senate Document 11. Commonwealth of Virginia. Retrieved from http://jlarc.virginia.gov/pdfs/reports/Rpt472.pdf

Kandalec, K. (2016). Perceptions of postsecondary career and technical education: A Q method examination. North Carolina State University Theses and Dissertations. Retrieved from https://repository.lib.ncsu.edu/handle/1840.20/33349

Kraemer, J., \& Craw, J. (2020). Statistic of the month: Vocational education and training systems for the 21 st century in Switzerland, German and Singapore. National Center on Education and the Economy [Online]. Retrieved from https://ncee.org/2014/11/statistic-of-the-month-vocationaleducation-training-systems-for-the-21st-century-in-switzerland-germany-singapore/

Leachman, M., \& Mai, C. (2014). Most states still funding schools less than before the recession Center on Budget and Policy Priorities. Retrieved from https://www.cbpp.org/research/most-states-stillfunding-schools-less-than-before-the-recession

Lohr, S. (2020, December 3). Up to 30 million in U.S. have the skills to earn $70 \%$ more, researchers say. [Online]. The New York Times. Retrieved from https://www.nytimes.com/2020/12/03/technology/work-skills-upwardmobility.html?action $=$ click\&module $=$ RelatedLinks\&pgtype $=$ Article

Malkus, N. (2019). The evolution of career and technical education: 1982-2013. American Enterprise Institute. Retrieved from https://www.aei.org/wp-content/uploads/2019/04/The-Evolution-ofCareer-and-Technical-Education.pdf

Markow, W., Restuccia, D., \& Taskka, B. (2017). The narrow ladder: The value of industry certifications in the job market. Boston, MA: Burningglass Technologies. Retrieved from https://www.burningglass.com/wp-content/uploads/BurningGlass_certifications_2017.pdf

Muller, R., \& Beatty, A. (2009). Work readiness certification and industry credentials: What do state high school policy makers need to know? Measures that Matter. Retrieved from https://www.achieve.org/files/WorkReadinessCertificationandIndustryCredentials.pdf

Opportunity@Work and Accenture [O@W]. (2020).Reach for the STARs. Realizing the potential of America's hidden talent pool. STARs Skilled Through Alternative Routes. Retrieved from https://opportunityatwork.org/wp-content/uploads/2020/10/Reach-for-the-STARsReport_final_081420-1.pdf

Passarella, A. (2018). Policy Brief: The necessary components of an effective career and technical education (CTE) program. Johns Hopkins School of Education: Institute for Education Policy. Retrieved from https://jscholarship.library.jhu.edu/bitstream/handle/1774.2/62979/cte-publishedfinal-cfc-final.pdf?sequence $=1$ \&isAllowed $=\mathrm{y}$

Pew Research Center. (2016, October 6). The state of American jobs" Social \& Demographic Trends. Retrieved from http://www.pewsocialtrends.org/2016/10/06/the-state-of-american-jobs/

Prebil, M., \& McCarthy, M.A. (2018, September). Building better degrees using industry certifications. Lessons from the field. New America. Retrieved from https://d1y8sb8igg2f8e.cloudfront.net/ documents/Building_Better_Degrees_Using_Industry_Certifications_2018-09-17_130631.pdf

Thomas, N., Marken, S., Gray, L., \& Lewis, L. (2013). Dual credit and exam-based courses in U.S. public high schools: 2010-11-First Look. National Center for Education Statistics. Retrieved from https://nces.ed.gov/pubs2013/2013001.pdf

Tucker, M. (2018). What, exactly, should the purpose of career and technical education be? College and Workforce Readiness. Opinion. Education Week [Online]. Retrieved from http://blogs.edweek.org/edweek/top_performers/2018/06/_what_exactly_is_career_and_technical education.html

U.S. Department of Education. (2013). National assessment of career and technical education: Interim report. Office of Planning, Evaluation and Policy Development, Policy and Program Studies Service. Retrieved from https://www2.ed.gov/rschstat/eval/sectech/nacte/careertechnical-education/interim-report.pdf 
Virginia Association for Career and Technical Education. (2018). Issues and solutions for career and technical education in Virginia 2018-2019. Retrieved from http://virginiaacte.org/documents/2018-19/issues_solutions_full.pdf

Virginia Department of Education (2020b). School accreditation ratings. Retrieved from https://www.doe.virginia.gov/statistics_reports/accreditation_federal_reports/accreditation/index. shtml\#qual

Virginia Department of Education. (2019). Data on industry credentialing in Virginia: Student pass percentage by credential. Retrieved from http://www.doe.virginia.gov/instruction/career_technical/path_industry_certification/index.shtml

Virginia Department of Education. (2020a). Academic and Career Plans of Study. Retrieved from http://www.doe.virginia.gov/instruction/career_technical/career_clusters/plans_of_study/index.sh tml

Zanville, H., \& Essien, F.S., Jr. (2019, June 27). Inside the big confusing credentialing tent: A new mission to understand non-degree credentials. The Evolution. Retrieved from https://evolllution.com/programming/credentials/inside-the-big-confusing-credentialing-tent-anew-mission-to-understand-non-degree-credentials/ 